\title{
The quality of business communications depending on attachment style, social emotional competences and personality traits
}

Article history:

Received: 12 Februar 2014

Sent for revision: 27 February 2014

Received in revised form: 12 November 2014

Accepted: 20 November 2014

Available online: 23 December 2014

\begin{abstract}
The main goal of this paper is to examine connection between attachment styles, emotional intelligence, life satisfaction, personality traits and humor styles with employed people, as well as to discuss implications of this connection on the quality of business communications. The survey includes 240 participants from Serbia. The structure of the convenience sample is heterogeneous and it includes employees and managers of both sexes and of a various age. The instruments used are: Emotional skills and competence questionnaire (Takšić, Moharić \& Munjas, 2006), Experiences in Close Relations (Kamenov \& Jelić, 2003), Personality Questionnaire (Zuckerman, 2002), Humor styles Questionnaire (Martin, Puhlik-Doris, Larsen, Gray \& Weir, 2003) and Satisfaction With Life Scale (Diener, Emmons, Larsen \& Griffin, 1985). The results indicate the existence of significant positive correlation between secure attachment style, affiliative and self-enhancing humor style, activity, sociability and life satisfaction. There is also a positive correlations between preoccupied attachment style and self- defeating humor style, and a moderate negative correlation between preoccupied attachment style, self- enhancing and aggressive humor style, activity, sociability as well as the overall life satisfaction.
\end{abstract}

Key words: attachment style, emotional intelligence, personality traits, humor style, life satisfaction, business communications

\footnotetext{
${ }^{1}$ Singidunum University, Faculty of media and communications, Belgrade, gordana.nikic@fmk.edu.rs

${ }^{2}$ Alfa University, Belgrade, PhD candidate in Economy

${ }^{3}$ Belgrade University, Faculty of Philosophy, PhD candidate in Psychology
} 
Nikić $\mathrm{G}$ et al.: The quality of business communications depending on attachment ...

\title{
Kvalitet poslovnih komunikacija u zavisnosti od stila afektivnog vezivanja, socijalno-emocionalnih kompetencija $i$ osobina ličnosti
}

\begin{abstract}
Apstrakt: Glavni cilj ovog rada je utvrđivanje povezanosti između stilova afektivne vezanosti, emocionalne inteligencije, zadovoljstva životom, osobina ličnosti i stilova humora, kod radno aktivnog stanovništva, kao i razmatranje implikacija ovih povezanosti na kvalitet poslovnih komunikacija. Istraživanje obuhvata 240 ispitanika iz Srbije.Struktura uzorka je prigodnog tipa, heterogena, čine ga zaposleni oba pola i različitog uzrasta. Korišćeni su instrumenti: Upitnik emocionalne kompetentnosti (Takšić, Moharić \& Munjas, 2006), Upitnik za procenu osobina ličnosti (Zuckerman, 2002), Iskustva u bliskim vezama - verzija za procenjivanje porodične afektivne vezanosti (Kamenov \& Jelić, 2003), Upitnik stilova humora (Martin, Puhlik-Doris, Larsen, Gray \& Weir, 2003) i upitnik Zadovoljstvo životom (Diener, Emmons, Larsen \& Griffin, 1985). Dobijeni rezultati ukazuju na postojanje značajne pozitivne povezanosti između sigurnog stila afektivne vezanosti, afilijativnog $i$ samopodržavajućeg stila humora, aktiviteta, socijabilnosti, kao i zadovoljstva životom. Dobijene su značajne negativne korelacije između preokupiranog stila afektivne vezanosti, samopodržavajućeg i agresivnog stila humora, aktiviteta, socijabilnosti, kao i ukupnog zadovoljstva životom, a pozitivne korelacije sa samopodređujućim stilom humora.
\end{abstract}

Ključne reči: stil afektivne vezanosti, emocionalna inteligencija, osobine ličnosti, stil humora, životno zadovoljstvo, poslovne komunikacije

\section{Introduction}

The life of current organisations has gone through a lot of changes in both macroeconomic and every-day communications. The intensity and tempo of those changes increase every-day stress and actualize the question of emotions and their expression. The latest studies (Berson \& Yammarino, 2006; Popper \& Amit, 2009) show that social emotional competences and intellectual flexibilities are vital for the achievement of the top results at work, especially in the sphere of management, but in the other segments of business as well.

It turned out that abilities, in the role of the predictors, explain only one part of the success at work, and the success formula is expanded by the facts connected to the motivation and working conditions, so it could look like this: success $=$ ability $\mathrm{x}$ motivation $\mathrm{x}$ working conditions (Petz, 1987). The latest studies show that the emotional competences are necessary in almost all 
Nikić $\mathrm{G}$ et al.: The quality of business communications depending on attachment ...

business segments. Namely, apart from having both physical activities and intellectual operations at work, man has to either play certain social roles, or to search for his right role, as it is the case with managing business. To fulfil that, certain suitable personal characteristics are needed, along with some interpersonal abilities (Čukić, 2003). The intellectual maturity is reflected in the realistic understanding of objective reality, openness towards new experiences, and broadness of interests, curiosity and relatively stable value system. On the other hand, emotional maturity is reflected in the ability to manage and regulate the emotions, self- assurance, ability to endure pressure and failure, creating permanent emotional relationships with other people and similar things. Keeping the emotional balance is one of the most important criteria of psychical health, and it supposes capacity for collaboration, having fun, relaxing, humour and expressing emotions in the socially acceptable way (Pajević, 2006).

Personal satisfaction depends a lot on the level of one's career satisfaction and the job he or she performs, as well as with the social reputation of that job. In the narrowest sense, job satisfaction is related to the positive emotional attachment of the single person to his/her job. There are some interesting researches about the connection between job satisfaction and general life satisfaction. Those researches appeared as a result of the phenomena often noticed - people who are not satisfied with their life are not usually satisfied with their job as well. The thing that is clearly confirmed is that life satisfaction and job satisfaction are connected only when a person considers a job highly important in his or her value system (Kabanoff, 1987). Theorists of humanism in psychology claim that people who self- actualize themselves can teach us what could be the ideal attitude towards the job under unfavourable conditions. These highly developed individuals assimilate their job into their identity, into their own being, i.e. their job actually becomes the part of their ego, their determination of their own personality (Maslov, 1998).

Researches performed by social psychologists (Kahn, 1995; Kummel, 1999) point out, on one hand, that emotional stability is of the crucial importance for performing managing jobs, but on the other hand, that the relationships at work are under the influence of the early family relationships, which coincides with Bowlby's attachment theory (Sharf, 1997).

Affective attachment is important not only for close relationships, but also for most of the relationships we start during life. This term was introduced into the science by John Bowlby (Bowlby, 1969/1982; 1988) and it presents specific, asymmetrical relationship which is formed in the earliest childhood between a mother and a child and which lasts during the whole life. From that point of view, looking for the closeness of certain persons who clearly differ from the others is the basic principle of the human behaviour and it had its own natural development, as well as the role in forming the human nature. In the 
Nikić $\mathrm{G}$ et al.: The quality of business communications depending on attachment ...

beginning, that theory was mainly focused on the child/parent relationship, as well as on the close relationships, but recently there is a rising interest of the researchers to apply the attachment theory on the business sphere. The attachment theory, as the dominant theory of emotional development of personality, is documented with a lot of empirical findings.

So far, the results suggest that the application of this theory on the understanding of the behaviour at work is justified, especially when it comes to the relationships with the authority (Kahn, 1995), solutions to the problems of employees (Kummel, 1999), communication strategies (Kummel, 1999), career development (Wright \& Perrone, 2008), stress handling and conflict solving (Kahn \& Kram, 1994).

It also turned out that emotional competencies, besides intellectual flexibility, are of the crucial importance for the success of managers (Kummel, 1999) and leaders (Manning, 2003), as well as for the development of the capacity for leading (Berson \& Yammarino, 2006; Popper \& Amit, 2009).

The question of affective attachment at work was not particularly considered before the end of 1990s. The first researches emphasize that the early experience of affective attachment is the part of our life and it follows us in the further development. The authors who start the attempts in this field are Hazan and Shaver, famous for their papers in the field of close romantic relationships (Hazan \& Shaver, 1990). They published a paper "Love and work" and they indicated the fact that working activity of the adults can be understood similarly to Bowlby's term "research". They approached the work of the adults as a form of researching, which we are differently engaged in, according to the attachment style. They are relying on the work of Mary Ainsworth (Ainsworth, 1978), who found that mothers who react sensitively and responsively to the signals and needs of their children during the first year of children's life (they notice child's signals, interpret them correctly and react fast and adequately) create preconditions for the secure attachment relationships. Hazan and Shaver start from three patterns of attachment with mother, identified by Ainsworth and her collaborators: secure, anxiousambivalent and avoidant and they apply them on the close romantic relationships, and then on the understanding of relationships at work.

The results of their research show that securely attached individuals show more certainty at work, higher degree of satisfaction and success at work and more self-confidence, while anxious- ambivalent individuals see work as the means to get the praise, often have the feeling of underestimation, they have the need to please others, often dream unrealistically about the success and the praise. The results of the research also show that avoidant emotional attachment supposes that the people with this kind of attachment like to work on their own, have problems with interrupting their obligations and understand the work as an excuse to avoid socialization, they are nervous when they do 
Nikić $\mathrm{G}$ et al.: The quality of business communications depending on attachment ...

not work and they often do harm for their own health. It turned out that employees with secure attachment style tend to better fit in at work and that the ones with anxious-ambivalent attachment styles are also anxious in their professions. The conclusion of studies so far is that, in stressful situations, people react according to their earliest experience (Rholes, Simpson \& Stevens, 1998) and that they have similar experience at work (Kahn \& Kram, 1994).

The main assumption of the attachment theory, which could explain behaviour at work, is that the behaviour of attachment is extended through the whole life span and that it is based on mental representations which are formed in the early childhood. Through regular interchanges with people and objects, a child creates inner working models of attachment as the mental representations of the world and important people in it, including a child himself. In different social situations at work, especially in stressful ones, the inner working models which determine both emotional reactions and the behaviour of employees are being activated. On the other hand, often dynamising "hard" and negative emotions, anger, anxiety, being hurt and depression, directly influences not only the behaviour of employees but as well the productivity of both the individuals and the teams.

The research that will be presented in this paper is dealing with the question of a connection of the attachment styles with other social emotional capacities (emotional intelligence, humour and general life satisfaction) and characteristics of the employees, as well as with the question of the implication of these variables on communication at work.

The instrument for measuring attachment, used in this article, is derived from four-category model of attachment (Bartholomew \& Horowitz, 1991) conceptualized for understanding family affective attachment (Kamenov \& Jelić, 2003). This model is derived directly from Bowlby's assumptions that there are two types of inner, working models of attachment- model of self and model of others (Bowlby, 1988). Each of these models can be presented as dichotomous- either positive or negative.

Bartholomew \& Horowitz presented the description of the behaviour of the various attachment styles in close relationships and the description of their reactions in stressful situations (Bartholomew \& Horowitz, 1991).

Positivity of the model of self induces the degree to which a person internalized the feeling of self- value, contrary to the feeling of anxiety and uncertainty because a person is not sure whether he or she deserves love of the others, while positivity of the model of other induces the degree to which one expects from the partner in the close relationship to be available and supportive. 
Nikić G. et al.: The quality of business communications depending on attachment ...

Secure ones have high level of self-esteem, positive attitude towards the others; they show high intimacy in the relationships. Model of self is positive, model of others is positive. They react to stress by fighting flexible and actively. They show a variety of strategies including the other as a source of support.

The preoccupied have a deep feeling of not being worth, they are preoccupied with relationships, fear of loneliness and they have a great need for closeness. Model of self is negative, while model of others is too positive. Their reaction to stress and problems is very intensive. When they do not feel well, they instantly address others. It is very difficult for them to solve their problems without the help from others.

The dismissing/avoidant avoid closeness with others because of the negative expectation they have, they keep their own values through compulsive selfrelying. Model of self is positive, while model of others is negative. In stressful situations, they become distant from their emotions and they diminish the importance of the problem. They actively avoid seeking the support from others and they are not emotionally neither reactive nor expressive.

The fearful/avoidant have low self-esteem, they lack trust in both self and the others. They avoid intimacy because of fear from being rejected and hurt. They have negative model of self and negative model of others. Their reaction to stress and problems is emotional, but they do not actively try to solve the problem.

\section{Methods and materials}

The main goal of this research is to examine correlations between the attachment styles and emotional intelligence, personality traits, humor styles and life satisfaction on the sample of employed people in Serbia.

\subsection{Hypothesis}

General hypothesis: It is expected that there is a statistically significant correlation between the attachment styles and emotional intelligence, life satisfaction, personality traits and humor styles with employed people in Serbia.

\section{Hypotheses:}

$\mathrm{H} 1.1$ It is expected that there is a statistically significant correlation between the secure attachment style, emotional intelligence, life satisfaction, personality traits and humor style. 
Nikić $\mathrm{G}$ et al.: The quality of business communications depending on attachment ...

$\mathrm{H} 1.2$ It is expected that there is a statistically significant correlation between the preoccupied attachment style, emotional intelligence, life satisfaction, personality traits and humor style.

$\mathrm{H} 1.3$ It is expected that there is a statistically significant correlation between the dismissing/avoidant attachment style, emotional intelligence, life satisfaction, personality traits and humor style.

$\mathrm{H} 1.4$ It is expected that there is a statistically significant correlation between the fearful/avoidant attachment style, emotional intelligence, life satisfaction, personality traits and humor style.

\subsection{Sample}

Choosing the sample, we paid attention to have approximately equal number of workers and managers in the companies, to have participants from all parts of Serbia and equal number of male and female participants. The sample is of convenience type and satisfies all the conditions given. The research covered 240 participants. According to the sex structure, the sample could be considered equable enough, $45 \%$ of the participants are males, and $55 \%$ females.

About $50 \%$ of the sample are workers, while the other half is constituted by managers and owners, $18 \%$ of which are departments managers, $12.5 \%$ owners, $12.1 \%$ sector managers, $7.5 \%$ top managers. Most of the examinees graduated from the university, and that is $47.5 \%$ of the complete number, $32 \%$ are people who finished only high school, while $15 \%$ of them graduated from college. There are only $5.4 \%$ with the highest degree of education. The youngest one is 20 years old, and the oldest is 65 , while the average age is 42. When it comes to the years in the service, the shortest period is a year, the longest 38 and the average is 17 . The most of the participants have the secure attachment style, almost $84 \%$. Then, there are participants with preoccupied style, $8.3 \%$, while the number of the participants with the dismissing/avoidant style is $4.6 \%$. Only $2.1 \%$ of the participants have the fearful/avoidant attachment style.

\subsection{Instruments and variables}

Emotional skills and competence questionnaire (ESCQ-45) with 45 items is used for the measuring of emotional intelligence. It is a short version of Emotional intelligence questionnaire UEK - 136 (Takšić et al, 2006) constructed according to the model of Salovey and Mayer (1990) and it estimates three aspects of emotional intelligence: capability to perceive and understand emotions (Perceive and Understand Emotions Scale), capability to express and label emotions (Express and Label Emotions Scale), capability 
Nikić $\mathrm{G}$ et al.: The quality of business communications depending on attachment ...

to manage emotions (Manage end Regulate Emotions Scale). All the scales have satisfactory reliability according to different samples, from $\alpha=0,71$ to $\alpha$ $=0,90$.

Personality Questionnaire for estimating dominant personality traits is used for personality type estimation ZKPQ (Zuckerman, 2002). This questionnaire consists of 99 items (a shorter version was used with 50 items, as it was suggested by the author himself) with the binary answer format. The dimensions of this questionnaire are: Activity (Act), Aggression-hostility (AggHost), Impulsive searching for sensations (ImpSS), Neuroticism and anxiety (N-Anx) and Sociability (Sy). Correlations on certain subscales (Zuckerman, 2002) were: for ImpSS (0.80), for N - Anx (0.84), for Agg - Host (0.78), for Act (0.76) and for Sy (0.83).

Questionnaire for measuring the family attachment is Experiences in Close Relations (Kamenov \& Jelić, 2003). It distinguishes 4 styles of attachment: dismissing avoidant, secure, fearful avoidant and preoccupied. It is a modified instrument (Brennan, Clark \& Shaver, 1998) which is initially used for measuring attachment in close romantic relationships. It turned out that this new instrument is suitable for measuring family attachment, half shortened, and that the content redundancy is being removed, and almost all the characteristics of the original instrument are being kept. The new economical scale has lost nothing of its reliability.

Humor Styles Questionnaire HSQ (Martin et al, 2003) is used for estimation of the humor styles. HSQ consists of four sub- scales: Afiliative humor style, Self- enhancing, Aggressive and Self- defeating style. The reliability of the whole scale is expressed with Cronbach's alpha, and it is 0.73.

Life satisfaction of the participants is measured with the Satisfaction with Life Scale - SWLS (Diener et al, 1985). SWLS is cognitive component of subjective well- being. The scale consists of five claims which participants answer to with a scale of seven degrees, Likert type.

Statistical interpretation of the data

We used Pearsons' coefficient of linear correlation on sub-dimensions of the styles of affective attachment, humor styles, dimensions of emotional intelligence and personality traits, as well as on the summation score on the life quality questionnaire. We decided to use this type of analysis because of the assumption about the existence of the linear correlation of these psychological phenomena, with the aim to check the set hypothesis of the research.

Using multiple regressive analyses, we determined the relations between secure and preoccupied attachment style as criterion and predictor variables: scores on subscales of humor styles, emotional intelligence, and the overall 
Nikić $\mathrm{G}$ et al.: The quality of business communications depending on attachment ...

score on the scale of life satisfaction and factor score on the first main components of the subscales of the questionnaires for the estimation of the dominant personality traits. We decided to use this type of analysis because of the assumption about the possibilities of the prediction of the affective attachment styles according to the observed group of predictors, with the aim to check the mail hypothesis of the research.

\section{Results}

As it has previously been mentioned, the aim of this article is to examine the correlations between the attachment styles, emotional intelligence, personality traits, humor styles and life satisfaction on the example of employed people in Serbia. Of all the statistic procedures used, we will show the results got with the correlational and regressive analysis.

Correlations between variables are shown in the following chart.

Table 1. Pearson's coefficient of linear correlation between the attachment styles and humor styles

\begin{tabular}{|c|c|c|c|c|c|}
\hline & & Secure & Preoccupied & Dismissing & Fearful \\
\hline \multirow[t]{2}{*}{ Affiliative style } & $\mathbf{R}$ & $.186\left(^{*}\right)$ & .084 & -.222 & -.412 \\
\hline & $P$ & .013 & .724 & .538 & .730 \\
\hline \multirow[t]{2}{*}{ Self-enhancing } & $\mathbf{R}$ & -.005 & $\begin{array}{l}-.159 \\
\end{array}$ & -.326 & .684 \\
\hline & $P$ & .941 & .504 & .329 & .316 \\
\hline \multirow[t]{2}{*}{ Aggressive style } & $\mathbf{R}$ & $-.158\left(^{*}\right)$ & 300 & -.062 & .075 \\
\hline & $P$ & .031 & .212 & .865 & .904 \\
\hline Self- defeating & $\mathbf{R}$ & $-.276(* *)$ & .398 & -.330 & .764 \\
\hline
\end{tabular}

Source: Authors' calculation 
Nikić $\mathrm{G}$ et al.: The quality of business communications depending on attachment ...

Table 2. Pearson's coefficient of linear correlation between the attachment styles and personality characteristics

\begin{tabular}{|l|c|c|c|c|c|}
\hline & & Secure & Preoccupied & Dismissing & Fearful \\
\hline $\begin{array}{l}\text { Neuroticism- } \\
\text { anxiety }\end{array}$ & $\mathbf{R}$ & $-.292(* *)$ & .132 & -.013 & -.140 \\
\hline & $\mathrm{P}$ & .000 & .580 & .970 & .823 \\
\hline \begin{tabular}{l} 
Impulsive $\begin{array}{l}\text { searching } \\
\text { sensations }\end{array}$ \\
\hline
\end{tabular} & $\mathbf{R}$ & -.006 & -.084 & -.401 & .694 \\
\hline Activity & $\mathrm{P}$ & .939 & .725 & .222 & .194 \\
\hline & $\mathbf{R}$ & $.197(* *)$ & -.438 & .601 & -.134 \\
\hline Sociability & $\mathrm{P}$ & .007 & .053 & .051 & .830 \\
\hline & $\mathbf{R}$ & .125 & -.178 & .207 & -.007 \\
\hline $\begin{array}{l}\text { Aggression } \\
\text { hostility }\end{array}$ & $\mathrm{P}$ & .087 & .454 & .541 & .990 \\
\hline & $\mathbf{R}$ & .116 & -.061 & -.504 & -.024 \\
\hline
\end{tabular}

Source: Authors' calculation

Table 3. Pearson's coefficient of linear correlation between the attachment styles and life satisfaction

\begin{tabular}{|c|c|c|c|c|c|}
\hline & & Secure & Preoccupied & Dismissing & Fearful \\
\hline & $P$ & .000 & .102 & .385 & .236 \\
\hline $\begin{array}{ll}\text { General } & \text { life } \\
\text { satisfaction } & \end{array}$ & $\mathbf{R}$ & -.015 & -.379 & .148 & -.584 \\
\hline & $P$ & .837 & .110 & .664 & .603 \\
\hline
\end{tabular}

Source: Authors' calculation 
Nikić $\mathrm{G}$ et al.: The quality of business communications depending on attachment ...

Table 4. Pearson's coefficient of linear correlation between the attachment styles and, emotional intelligence

\begin{tabular}{|l|c|c|c|c|c|}
\hline & & Secure & Preoccupied & Dismissing & Fearful \\
\hline $\begin{array}{l}\text { Perceive and } \\
\text { understand } \\
\text { emotions }\end{array}$ & $\mathbf{R}$ & -.034 & -.284 & .340 & .925 \\
\hline $\begin{array}{l}\text { Express and label } \\
\text { emotions }\end{array}$ & $\mathrm{P}$ & .649 & .225 & .306 & .075 \\
\hline & $\mathrm{P}$ & .011 & .582 & .878 & .619 \\
\hline $\begin{array}{l}\text { Manage and } \\
\text { regulate emotions }\end{array}$ & $\mathbf{R}$ & -.127 & -.001 & .306 & .013 \\
\hline & $\mathrm{P}$ & .089 & .997 & .390 & .983 \\
\hline
\end{tabular}

Source: Authors' calculation

Statistically significant Pearson's coefficient of linear correlation is found only between the secure attachment style and the following variables: affiliative humor style (with positive sign and of a low intensity), aggressive and selfenhancing humor style (with negative sign and of a low intensity), expressing and labelling emotions (with positive sign and low intensity), neuroticism (with negative sign and low intensity) and activity (positive sign and low intensity).

There is no statistically significant correlation between two styles of attachment: dismissing and fearful style with emotional intelligence, personality traits, humor style and life satisfaction. This result could be explained by a very low representation of the fearful and dismissing style in the sample.

\subsection{Results of the regression analysis}

In the research, each of the attachment styles (secure, preoccupied, dismissing and fearful) is observed as criterion variable, while for the predictors variables we took: scores on the humor styles, subscales of emotional intelligence, as well as the finals score on the scale of life satisfaction and factor scores on the first main components of the subscales for the estimation of dominate personality characteristics.

Multiple regression analysis with the secure attachment style as a criterion variable 
Nikić $\mathrm{G}$ et al.: The quality of business communications depending on attachment ...

Table 5. Coefficient of multiple correlations

\begin{tabular}{|l|c|c|c|c|}
\hline Model & $\begin{array}{c}\text { R Coefficient of } \\
\text { multiple correlation }\end{array}$ & $\begin{array}{c}\mathrm{R}^{2} \text { Square of coefficient } \\
\text { of multiple correlation }\end{array}$ & Adjusted $\mathrm{R}^{2}$ & Std. error \\
\hline 1 & $.602(\mathrm{a})$ & .363 & .296 & 7.59932 \\
\hline
\end{tabular}

Source: Authors' calculation

Table 6. The average significance of the regressive model

\begin{tabular}{|l|l|c|c|c|c|c|}
\hline Model & $\begin{array}{c}\text { Square } \\
\text { amount }\end{array}$ & $\begin{array}{c}\text { Number of } \\
\text { degrees of } \\
\text { freedom }\end{array}$ & $\begin{array}{c}\text { Average } \\
\text { square } \\
\text { number }\end{array}$ & F test & $\begin{array}{c}\text { P } \\
\text { importance } \\
\text { level }\end{array}$ \\
\hline 1 & Regression & 4075.648 & 13 & 313.511 & 5.429 & .000 \\
\hline & Residual & 7160.960 & 124 & 57.750 & & \\
\hline
\end{tabular}

Source: Authors' calculation

Regression model is statistically significant on the level $p=0,000$. Coefficient of multiple correlations is $\mathrm{R}=0,602$ and a group of predictors explains about $36 \%$ of variability of the variable system. According to these results we can say that there is a higher level of connection between criteria variable and predictive set of variables.

Statistically significant beta coefficients have affiliative and self- enhancing humor style, life satisfaction, sociability and activity. All beta coefficients are of a positive sign and of a low to moderate intensity. Such results suggest that, as the participants show higher degree of secure attachment style, their affiliative and self-enhancing humor style is more intensive, they are satisfied with their life and they express more activity and sociability. 
Nikić $\mathrm{G}$ et al.: The quality of business communications depending on attachment ...

Table 7. Partial contribution to the predictors

\begin{tabular}{|l|c|c|c|}
\hline & $\begin{array}{c}\text { Beta } \\
\text { coeff } \\
\text { icient }\end{array}$ & t-test & $\begin{array}{c}\text { p-level of } \\
\text { significance }\end{array}$ \\
\hline (Constant) & & 5.613 & .000 \\
\hline Affiliative humor style & .302 & 3.185 & .002 \\
\hline Self- enhancing humor style & .242 & $\mathbf{2 . 5 6 0}$ & .012 \\
\hline Aggressive humor style & .051 & .583 & .561 \\
\hline Self- defeating humor style & .126 & 1.371 & .173 \\
\hline Life satisfaction & .211 & $\mathbf{2 . 6 2 2}$ & .010 \\
\hline Perceive and understand emotions & .043 & .436 & .664 \\
\hline Express and label emotions & .057 & .536 & .593 \\
\hline Regulate and manage emotions & .013 & .117 & .907 \\
\hline Neuroticism- anxiety & -.040 & -.482 & .631 \\
\hline Impulsive searching for sensations & -.105 & -1.168 & .245 \\
\hline Activity & .227 & $\mathbf{2 . 8 4 0}$ & .005 \\
\hline Sociability & .420 & 4.919 & .000 \\
\hline Aggression-hostility & .131 & 1.633 & .105 \\
\hline
\end{tabular}

Source: Authors' calculation

2) Multiple regression analyses with preoccupied style as a criterion variable.

Table 8. Coefficient of multiple correlations

\begin{tabular}{|c|c|c|c|c|}
\hline Model & $\mathrm{R}$ & $\mathrm{R}^{2}$ & Adjusted $\mathrm{R}^{2}$ & Std. error \\
\hline 1 & .383 & .146 & .073 & 5.13700 \\
\hline
\end{tabular}

Source: Authors' calculation

Table 9. Percentage of the significance of regression style

\begin{tabular}{|l|l|l|l|l|l|l|}
\hline Model & & $\begin{array}{l}\text { Square } \\
\text { number }\end{array}$ & $\begin{array}{l}\text { Numb of } \\
\text { degrees } \\
\text { of } \\
\text { freedom }\end{array}$ & $\begin{array}{l}\text { Average } \\
\text { square } \\
\text { number }\end{array}$ & $\mathrm{F}$ & $\mathrm{P}$ \\
\hline 1 & Regression & 679.312 & 13 & 52.255 & 1.980 & .026 \\
\hline & Residual & 3958.316 & 150 & 26.389 & & \\
\hline & Total & 4637.628 & 163 & & & \\
\hline
\end{tabular}

Source: Authors' calculation 
Nikić $\mathrm{G}$ et al.: The quality of business communications depending on attachment ...

Regressive model is statistically significant on the level $p=0,026$. Coefficient of multiple correlations is $\mathrm{R}=0,383$ and a set of predictors explains about $15 \%$ of variability of variable system. According to these results it could be said that there is moderate level of connection between criteria variable and predictive set of variables

Table 10. Partial contribution of predictors

\begin{tabular}{|l|c|c|c|}
\hline & Beta & $\mathrm{T}$ & Sig. \\
\hline (Constant) & & 23.481 & .002 \\
\hline Affiliative humor style & .221 & 2.786 & .108 \\
\hline Self- enhancing humor style & $\mathbf{- . 6 2 8}$ & $\mathbf{- 9 . 3 7 3}$ &. $\mathbf{0 1 1}$ \\
\hline Aggressive humor style & $\mathbf{- . 4 1 3}$ & $\mathbf{- 4 . 8 7 9}$ &. $\mathbf{0 4 0}$ \\
\hline Self- defeating humor style & .993 & $\mathbf{1 2 . 2 2 3}$ &. $\mathbf{0 0 7}$ \\
\hline Life satisfaction & $\mathbf{- . 8 6 8}$ & $\mathbf{- 1 4 . 3 2 3}$ &. $\mathbf{0 0 5}$ \\
\hline Perceive and understand emotions & .361 & 3.708 & .066 \\
\hline Express and emotions & -.273 & -3.543 & .071 \\
\hline Regulate and manage emotions & .042 & .501 & .666 \\
\hline Neuroticism- anxiety & .001 & .015 & .989 \\
\hline Impulsive searching for sensations & -.821 & $-\mathbf{1 0 . 6 6 9}$ &. $\mathbf{0 0 9}$ \\
\hline Activity & -.286 & $-\mathbf{4 . 3 8 1}$ &. $\mathbf{0 4 8}$ \\
\hline Sociability & -.132 & -1.228 & .344 \\
\hline Aggression- hostility & .024 & .363 & .751 \\
\hline
\end{tabular}

Source: Authors' calculation

The following predictors give statistically significant partial contribution to predication of criteria: self- defeating humor style (with positive sign and of a very high intensity), self- enhancing and aggressive humor style (with negative sign and of a medium intensity), life satisfaction (with negative sign and of a high intensity), impulsive searching for sensations (with negative sign and with higher intensity) and activity (with negative sign and of a lower intensity). This result suggests that if a person has more dominant preoccupied humor style, have more dominant self- defeating humor style, and less dominant self- enhancing and aggressive humor style, life satisfaction, activity and impulsive searching for sensations will be on the lower level as well.

\section{Discussion}

With the basis in the theory and researches previously done, in this paper, we start from the assumption that the emotional security is gained in the early 
Nikić $\mathrm{G}$ et al.: The quality of business communications depending on attachment ...

childhood and it is the basis on which we develop other social emotional competencies as emotional intelligence, humor, and many other personal characteristics and general life satisfaction.

The results of our research (charts $1,2,4,7$ ) indicate that if the participants show higher dominance of secure attachment style, they have more dominant affiliative and self-enhancing humor style, they are more satisfied with life and they have more dominant activity and sociability, and they are not apt to selfdefeating and aggressive humor style. It could be explained with their own positive model of self and positive model of others. The feeling of inner security influences their general life satisfaction which they implement in all fields of life. The secure have lower score on anxiety and neuroticism tests, and they have better emotional self- regulation (chart 2), which means that they are not tense, upset and they are not sensitive to criticism. All the results imply the expectation that the secure will be more successful in creating the contact with the others, constructive solutions to conflicts at work and that they will overcome the consequences of the stress at work easier.

The result implies the expectation that more developed emotional competences can help easier contact with other people and easier endurance of stress at work. Emotional stability of managers is very important in stressful situations, bearing in mind that they communicate with the employees, clients and officials every day. The feeling of security, whether it comes from the inner working models or the current affective attachments, influences both the behaviour in stressful situations and important decisions and conflict solving.

The results of our research (chart 10) indicate that the people with the preoccupied style are more prone to self- defeating humor style. It could be explained by their inner negative model of self. In other words, in the presence of other people, they behave as if they felt bad in their own skin. At the same time, humour (jokes and jests) neither motivates nor does it support them, bearing in mind less dominant self- enhancing humor style. Preoccupied style is not inclined to aggressive humor because their attention and respect they get from other people mean a lot to them. Their model of others is too positive, they are prone to idealize others because their selfconfidence depends on the others' support. Bearing in mind that this theory suggests that they are more prone to conforming and taking the defeating position, a lack of aggressive humor style with preoccupied participants is expectable result. Lack of self-confidence and negative understanding of one's own competences influence the drop in the level of general life satisfaction with preoccupied style.

Their general life dissatisfaction probably has its roots from the childhood and the needs for parental care and love which were not satisfied, and then it became the inner feeling and experience of dissatisfaction which is transferred to all other fields of life. The preoccupied react very intensively in 
Nikić $\mathrm{G}$ et al.: The quality of business communications depending on attachment ...

stressful and conflict situations, they have weak emotional self- regulation for everything that can negatively influence their behaviour in business communication. They do not have any tendency toward new challenges and explorations, i.e. they have tendency toward security, which also has the implications for the type of the job the most suitable for them.

The results of this research are in correlation with the results of the similar researches in the world.

In the researches of the humor styles, it also turned out that (Kazarian \& Martin, 2004; Saroglou \& Scariot, 2002) the participants of the secure attachment style are more inclined toward affiliative and self- enhancing humor style, while avoidant have the lowest scores at affiliative style.

The researches of the connection of the attachment styles and the styles of conflict solving show that the only one inclined toward constructive strategies is secure attachment style. In conflict situations, the preoccupied react intensely, the insecure mostly avoid conflicts, and the avoidant have the most destructive tactics - withdrawal, rejecting and hostile behaviour (Pietromonaco, Greenwood, Feldman \& Barrett, 2004; Du Plessis, 2006; Steuber, 2005; Domingue \& Mollen, 2009)

In the research of business communication, the results indicate that secure style is positively connected with self- estimation, emotional intelligence, extroversion, pleasantness, kindness and self-awareness in business communication and with the business efficiency (Elizabeth. ChamorroPremuzic \& Furnham, 2010). The results also indicate that the attachment styles are connected with leadership, trust and pleasure at work.

The research of emotional intelligence showed that there in the influence of the attachment styles and emotional intelligence on various communication types. While attachment styles are relatively stable during the time, emotional intelligence ability can be influenced with the training (Cherry, 2013).

Hazan and Shaver had similar results in their own research which shows that the preoccupied attachment style is often followed by dissatisfaction at work and instrumentalization of work as a means to get the praise and attention from the others (Hazan \& Shaver, 1990). Kummel discovers that the high score at preoccupation is in the considerable correlation with anxiety because of the work performance and a care for the relationships at work (Kummel, 1999). Primary nurturers are the first authority figures; as such, they are setting the model for people's future expectations at work. On the other hand, the inner models of attachment are being initiated under the influence of feeling of anxiety. When the people maintain uncertainty and stress in some situation at work, their inner models are being activated leading them to reject or to create the relationships, remaining independent, until they feel secure again. This is especially important for understanding the behaviour of 
Nikić $\mathrm{G}$ et al.: The quality of business communications depending on attachment ...

preoccupied, because they do not have positive picture about themselves, and they see the work as a means to get new a new praise or a support by the others. They also often have feelings of subordination, and they have the need to satisfy the others, unrealistically dreaming about the success and praises.

Our and the results of many other researchers suggest that identifying models of attachment of an individual, especially insecure models, can lead us to valuable information about the approach to collaboration with others, selfrespect and sociability of an individual, either the case is about the relationship with the superiors (supervisor, chief, manager or chief executive) or with other employees. It could be expected, especially in the stressful periods, that some problems will appear because of the unconscious use of the working models, especially in the manager- employee relationship. This idea requires further investigation. Until now, it turned out that indirect managing is the process filled with emotions and moods, form both perspective - manager's and employee's. Understanding and knowing the emotions and the ability to cope with them is especially important for the managers because they work in special social context where constant indirect interaction with employees and clients is the necessity.

\section{Conclusion}

The results of this research showed that the participants with the secure attachment style are sociable, have more dominant activity and are prone to humor styles which support their own personality and the personality of others. They are also satisfied with life comparing to the insecure participants. On the other hand, people with preoccupied style are prone to self-defeating humor style, they support themselves less with humor and they are less aggressive.

The results of our research suggest that the participants with the secure attachment style will easily find their own way out from the requiring conditions of the contemporary business practice, in the working atmosphere literally packed with emotions. In our organisations, the situation is even more dramatic because of the difficult working conditions, uncertainty, general poverty which all together enhances every day struggle for the existence, competition and competence, uncertainty, not so big opportunity for the progress and recognition.

Every day stress is activating behaviour according to the dominant attachment emotional competence of all of the participants in the communication is of the vital importance for achieving business results. In stressful and intense situations, employees often ask for the support from managing teams and 
Nikić $\mathrm{G}$ et al.: The quality of business communications depending on attachment ...

leaders as the ones responsible for the basic conclusions. Affective security of the manager plays an important role in overcoming stress consequences, decision-making in crisis and effective conflict solving in the team.

These results are only the beginning of the researches with the aim to show to which extent social emotional competences and emotional security of the employees and managers influence business results. The suggestion for the potential researches is to widen the sample and to include larger number of top managers. It should also include the larger number of other attachment styles in the sample (dismissing and avoidant) making statistic analysis possible. Finally, it is necessary to use the scales for direct assessment of different aspects of performance and success at work.

\section{References}

Ainsworth, M., Blehar, M., Waters, E., \& Wall, S. (1978). Patterns of attachment: A Psychological Study of the Strange Situation. Hillsdale, New Jersey.

Bartholomew, K., \& Horowitz, L.M. (1991). Attachment styles among young adults: A test of a four-category model. Journal of Personality and Social Psychology, 61(2), 226-244. doi:10.1037/0022-3514.61.2.226

Bowlby, J. Attachment and loss. Attachment. New York: Basic Books.

Bowlby, J. (1988). A secure base: Parent-child attachment and healthy human development. New York: Basic.

Berson, Y., Dan, O., \& Yammarino, F.J. (2006). Attachment style and individual differences in leadership perceptions and emergence. J Soc Psychol, 146(2), 165-82. pmid:16673846

Brennan, K.A., Clark, C.L., \& Shaver, P.R. (1998). Self-report measurement of adult attachment. An integrative overview. In J.A. Simpson \& W.S. Rholes (Eds.), Attachment theory and close relationships. (pp. 46-76). New York: Guilford Press.

Čukić, B. (2003). Psihologija rada - usklađivanje čoveka i posla. Kruševac: Istraživački centar za industrijski menađment plus.

Hazan, C., \& Shaver, P.R. (1990). Love and work: An attachment theoretical perspective. Journal of Personality and Social Psychology, 52, 511-524.

Diener, E., Emmons, R.A., Larsen, R.J., \& Griffin, S. (1985). The Satisfaction with Life Scale. Journal of Personaliyu Assessment, 49, 71-75.

Hutt, M.J. (1991). Influences of attachment in everyday problem solving. Cornell University.

Kabanoff, B. (1987). Predictive validity of the MODE conflict instrument. Journal of Applied Psychology, 72, 160-163.

Kahn, W.A., \& Kram, K.E. (1994). Authority at work: Internal models and their organizational consequences. Academy of Management Review, 19(1), 17-50.

Kahn, W.A. (1995). Organizational Change and the Provision of a Secure Base: Lessons from the Field. Human Relations,48(5), 489-514. doi:10.1177/001872679504800503 
Nikić $\mathrm{G}$ et al.: The quality of business communications depending on attachment ...

Kamenov, Z., \& Jelić, M. (2003). The validation parameter for assessing the degree of attachment in different types of close relationships: Modification of Brennan Inventory of experiences in close relationships. Contemporary Psychology,6(1), 73-92.

Kummel, P.E. (1999). Bringing your family to work: Attachment in the workplace. Columbia University. Doctoral dissertation.

Manning, T.T. (2003). Leadership across cultures: attachment style influences. Journal of Leadership \& Organizational Studies, 59.

Martin, R.A., Puhlik-Doris, P., Larsen, G., Gray, J., \& Weir, K. (2003). Individual differences in uses of humor and their relation to psychological well-being: Development of the Humor Styles Questionnaire. Journal of Research in Personality, 37, 48-75.

Maslov, A. (1998). Psihologija u menadžmentu. Beograd: Adizes Southeast Europe.

Pajević, D. (2006). Psihologija rada. Beograd: Liber.

Petz, B. (1987). Psihologija rada. Zagreb: Školska knjiga.

Popper, M., \& Amit, K. (2009). Influence of attachment style on major psychological capacities to lead. J Genet Psychol,170(3), 244-67. pmid:19928318

Rholes, W.S., Simpson, J.A., \& Stevens, J.G. (1998). Attachment Orientations, Social Support, and Conflict Resolution in Close Relationships. In Attachmnet Theory and Close Relationships. (pp. 166-188). New York: Guilford Press.

Salovey, P., \& Mayer, J.D. (1990). Emotional Intelligence. Imagination. Cognition and Personality, 9.

Sharf, R.S. (1997). Applying Career Development Theory to Counseling. Brooks/Cole Publishing Company, International Thompson Publishing.

Takšić, V., Moharić, T., \& Munjas, R. (2006). Emocionalna inteligencija: Teorija, operacionalizacija, primjena $i$ povezanost s pozitivnom psihologijom. Rijeka: Filozofski fakultet.

Zuckerman, M. (2002). Zuckerman-Kuhlman Personality Questionnaire (ZKPQ): An alternative five factorial model. In B. Deraad \& M. Peru-sini (Eds.), Big Five Assessment. (pp. 377-396). Seattle: Hogrefe and Huber Publishers.

Wright, L., \& Perrone, M. (2008). The Impact of Attachment on Career-Related Variables: A Review of the Literature and Proposed Theoretical Framework to Guide Future Research. Journal of career development, 87-106. december. 